\title{
Design and Simulation of Robust Controllers for Power Electronic Converters used in New Energy Architecture for a (PVG)/ (WTG) Hybrid System
}

\author{
Mohamed Akram JABALLAH \\ UR-LAPER, Faculty of Sciences of \\ Tunis, University of Tunis El Manar \\ Tunis, Tunisia
}

\author{
Dhafer MEZGHANI \\ UR-LAPER, Faculty of Sciences of \\ Tunis, University of Tunis El Manar \\ Tunis, Tunisia
}

\author{
Abdelkader MAMI \\ UR-LAPER, Faculty of Sciences of \\ Tunis, University of Tunis El Manar \\ Tunis, Tunisia
}

\begin{abstract}
The use of the combination of photovoltaic energy source and the wind energy source as a hybrid configuration has become an alternative solution to produce power energy to fed industrial and domestic applications. In order to fully exploit the energy provided by both sources and ensure a very high efficiency it is necessary to oblige the hybrid power system to produce the maximum possible power. Indeed, in the applications based on renewable energy, power converters are used as an essential element that can help the global energy system to extract maximum power. This paper focuses on developing and optimising of a new architecture for hybrid photovoltaic generator (PVG) / wind turbine generator (WTG) power energy. To obtain the maximum power, two kinds of MPPT procedures have been used: the first is based on MPPT (P\&O) sliding mode control (MPPTSMC) for the photovoltaic generator (PVG), and the second is a control based on MPPT current control (MPPTCC) approach and that for the wind turbine generator (WTG). In addition, the proposed hybrid power system can work very well under changes of climatic conditions, such as irradiation and wind speed. On the other hand, in order to maintain dc-link at a desired and stable value, during these variations, we have integrated a boost converter controlled by a sliding mode controller (SMC). A simulation model for the hybrid power system has been carried out using PSIM tools.
\end{abstract}

Keywords-(PVG)/(WTG) Hybrid system; (MPPTSMC); (MPPTCC); Wind turbine generator (WTG); Photovoltaic generator $(P V G)$

\section{INTRODUCTION}

The electricity demand is rapidly growing all over the world. Indeed, photovoltaic and wind power sources produce a large amount of energy and are able to cover this need. A system of energy production based on a photovoltaic generator (PVG)/wind turbine generator (WTG) hybrid system can be used in two famous applications namely: standalone application [1], [2], [3] and grid-connected applications [4], [5]. In addition, a hybrid power system may also include power converters, a storage system and a control unit for load management. Nevertheless, to satisfy load request, the system should present a good exploitation and a high general efficiency. For that, it is necessary to extract the maximum of power from these two energy sources. MPPT is a necessary part in (PVG)/(WTG) hybrid system configuration.
Various techniques of maximum power tracking (MPPT) have been considered in renewable power applications. For the photovoltaic generator (PVG), the perturbation and observation (P\&O) method allow MPP tracking even in changing environmental conditions [6], [7]. For the wind turbine generator applications, various methods have been developed in [8], [9]. Sliding mode control is used, in many research studies, to track the maximum power point (MPP) in photovoltaic applications [10], [11] [12], [13].The main advantage of the sliding mode technique is the simplicity of implementation, robustness, and the great performance. In this work two types of MPPT procedure have been used: the first is based on MPPT (P\&O) sliding mode control (MPPTSMC) for the photovoltaic generator (PVG), the second is based on MPPT current control (MPPTCC) approach for the wind turbine generator (WTG). In this research, the renewable hybrid source of energy is used to supply continuous power to the standalone application. So, in order to achieve a constant dc-link voltage, a robust sliding mode control (SMC) controller is applied to a dc-dc boost converter interposed between the two sources and the used load.

A number of researches have discussed the control of different configurations architecture for hybrid (PVG/WTG) system energy [1], [2], [3],[4], [5]. While the present paper is the first one, to the best of the authors' knowledge, whose propose a new architecture based on two dc-dc buck converters coupled in parallel, cascaded with a dc-dc boost converter.

This paper is organised as follows: In Section 2, the global hybrid energy system is described. In Section 3, the dc-dc power stage is analysed. The Modeling of the battery bank is presented in Section 4. The theoretical study of control strategies is discussed in Section 5. The simulation results under PSIM software tools are interpreted in Section 6. The conclusion is addressed in the last of this work.

\section{GLOBAL (PVG)/(WTG) HYBRID SYSTEM}

The proposed hybrid system consists of a wind turbine generator (WTG), a permanent magnet synchronous generator (PMSG), a three phase uncontrolled rectifier converter, a photovoltaic generator (PVG), two dc-dc buck power converters, a dc-dc boost power converter, a common battery bank storage and a load connected, as shown in Figure 1. 


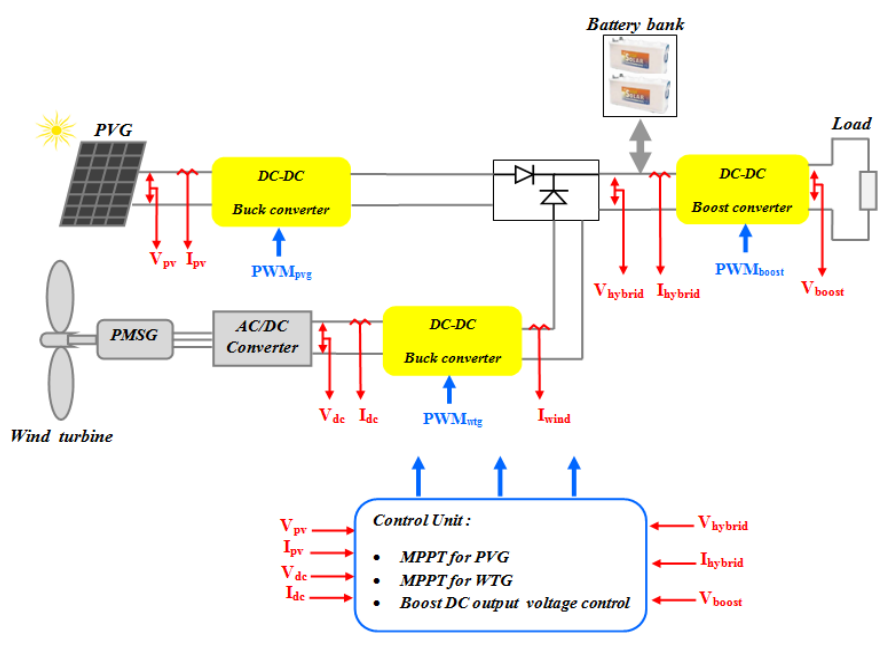

Fig. 1. The global (PVG)/(WTG) hybrid system.

\section{A. Modelling of the photovoltaic generator $(P V G)$}

A photovoltaic cell can be described by the equivalent circuit diagram in Figure 2, constituted by a source of current $\mathrm{I}_{\mathrm{ph}}$, depending on the photovoltaic irradiance in parallel with a diode and a shunt resistor $\mathrm{R}_{\mathrm{sh}}$, the all in series with a resistance $R_{s}$. The simplified equivalent electric system of a photovoltaic cell designated by the coming equations [14], [15]:

$I_{P V}=I_{P h}-I_{d}$

$I_{d}=I_{S} \cdot\left[\exp \left(\frac{q \cdot V_{P V}}{A \cdot k \cdot T}\right)-1\right]$

$I_{P h}=\left[I_{S C}+K_{I} \cdot\left(T-T_{\operatorname{Re} f}\right)\right] \cdot \frac{S}{S_{r}}$

$I_{S}=I_{R S} \cdot\left(\frac{T}{T_{\mathrm{Re} f}}\right)^{\left(\frac{3}{A}\right)} \cdot \exp \left[\frac{q \cdot E_{g a p}}{A \cdot k}\left(\frac{1}{T_{\mathrm{Re} f}}-\frac{1}{T}\right)\right]$

$I_{R S}=\frac{I_{S C}}{\exp \left(\frac{q \cdot V_{O C}}{A \cdot k \cdot T_{\mathrm{Re} f}}\right)-1}$

$I_{P V}=I_{P h}-I_{S} \cdot\left[\exp \left(\frac{q \cdot\left(V_{P V}+I_{P V} \cdot R_{S}\right.}{A \cdot k \cdot T}\right)-1\right]-\left(\frac{V_{P V}+I_{P V} \cdot R_{S}}{R_{S h}}\right)$

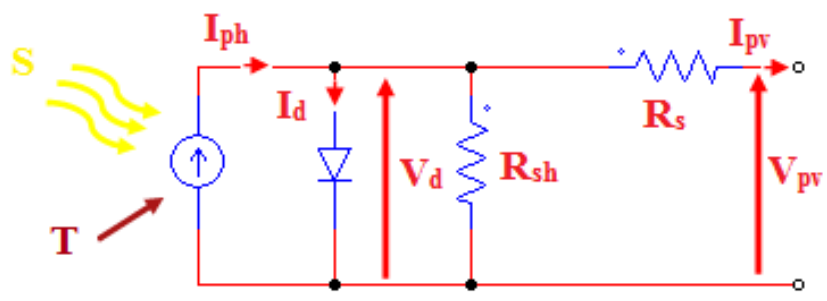

Fig. 2. The equivalent electric circuit of a photovoltaic cell
Where $\mathrm{q}$ is the charge of the electron, $\mathrm{A}$ is diode ideality factor, $\mathrm{k}$ is Boltzmann's constant, and T is the cell's operating temperature in kelvin. $\mathrm{I}_{\mathrm{S}}$ is the cell dark saturation current. $\mathrm{I}_{\mathrm{SC}}$ is the short-circuit current, $\mathrm{K}_{\mathrm{I}}$ is the temperature coefficient of the cell's short circuit (Amperes/ $\mathrm{K}$ ), $\mathrm{T}_{\mathrm{Ref}}$ is the cell reference temperature in kelvin, $S$ is the solar irradiance in $W / \mathrm{m}^{2}$ and $S_{r}$ represents the reference solar irradiance $\left(\mathrm{W} / \mathrm{m}^{2}\right), \mathrm{S}_{\mathrm{r}}=$ $1000\left(\mathrm{~W} / \mathrm{m}^{2}\right) . \mathrm{V}_{\mathrm{OC}}$ is the open-circuit voltage at reference temperature $T_{\text {Ref. }} I_{R S}$ is the cell's reverse saturation current in ampere at $\mathrm{T}_{\text {Ref }}$, and the solar radiation $1000\left(\mathrm{~W} / \mathrm{m}^{2}\right)$. $\mathrm{E}_{\text {gap }}$ is the band-gap energy of the semiconductor used in the cell.

The characteristics $\mathrm{P}_{\mathrm{pv}}\left(\mathrm{V}_{\mathrm{pv}}\right), \mathrm{I}_{\mathrm{pv}}\left(\mathrm{V}_{\mathrm{pv}}\right)$ under different irradiance levels is shown in Figure 3 and the characteristic $\mathrm{P}_{\mathrm{pv}}\left(\mathrm{V}_{\mathrm{pv}}\right), \mathrm{I}_{\mathrm{pv}}\left(\mathrm{V}_{\mathrm{pv}}\right)$ under different temperature is shown in Figure 4. As illustrated in the figures, the temperature have a commanding influence on the open circuit voltage $\mathrm{V}_{\mathrm{OC}}$, and photovoltaic irradiance has an impact on the short-circuit current.

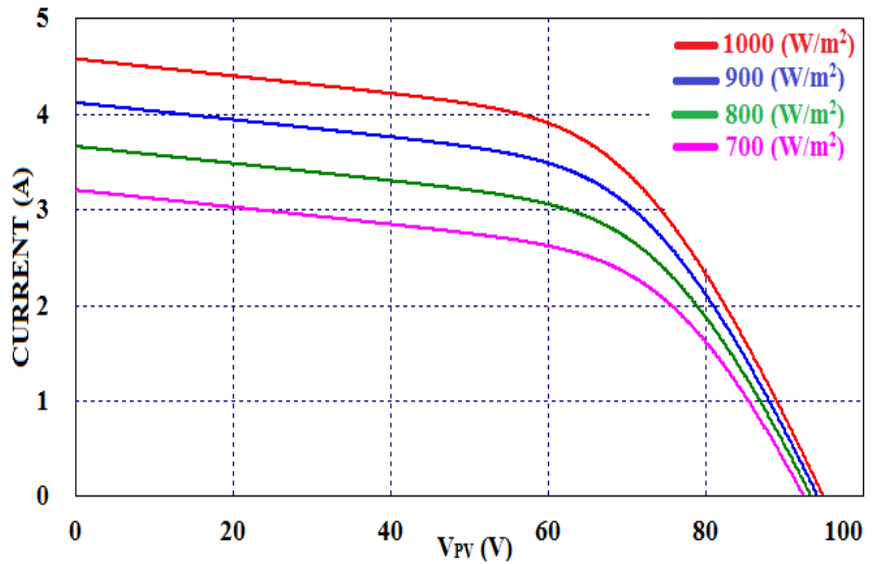

(a)

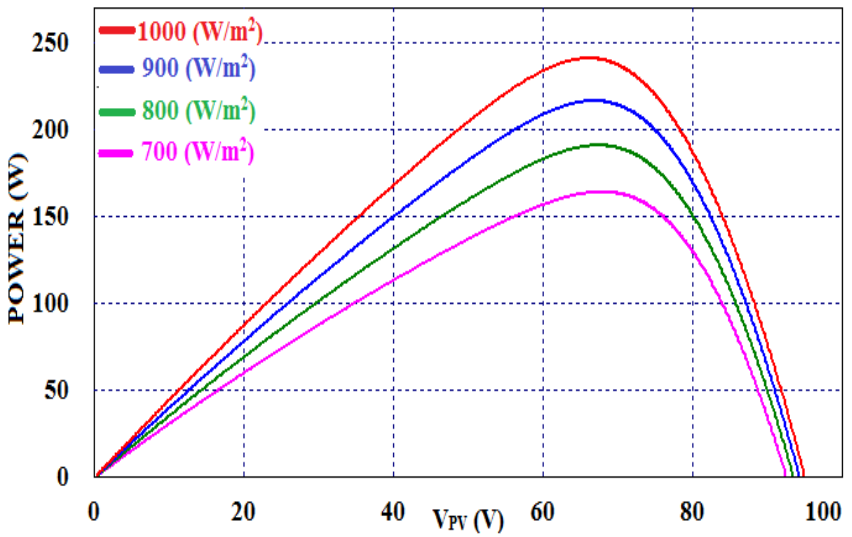

(b)

Fig. 3. Photovoltaic generator characteristics under different level of irradiance and at $\left(25^{\circ} \mathrm{C}\right)$ : (a) $\mathrm{I}_{\mathrm{pv}}=\mathrm{f}\left(\mathrm{V}_{\mathrm{pv}}\right)$, (b) $\mathrm{P}_{\mathrm{pv}}=\mathrm{f}\left(\mathrm{V}_{\mathrm{pv}}\right)$ 


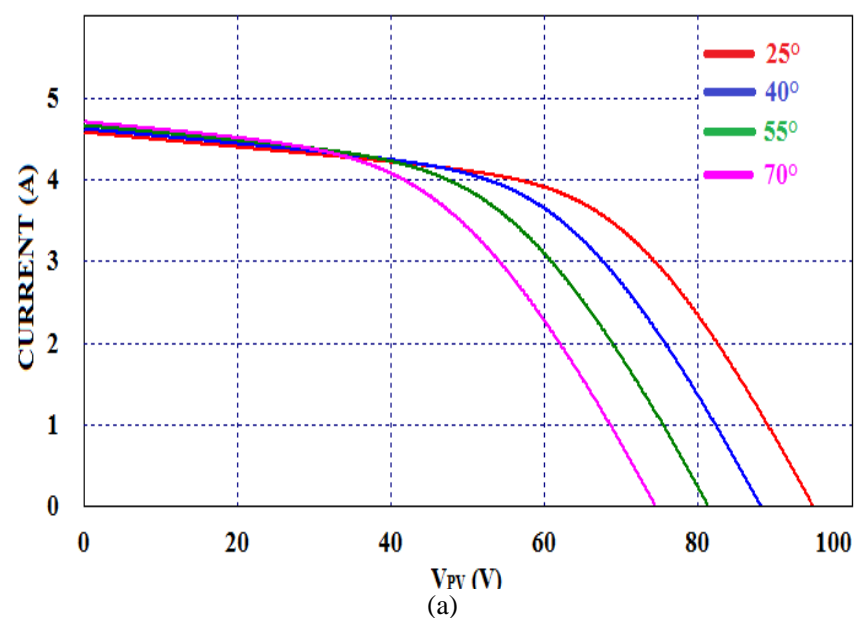

(a)

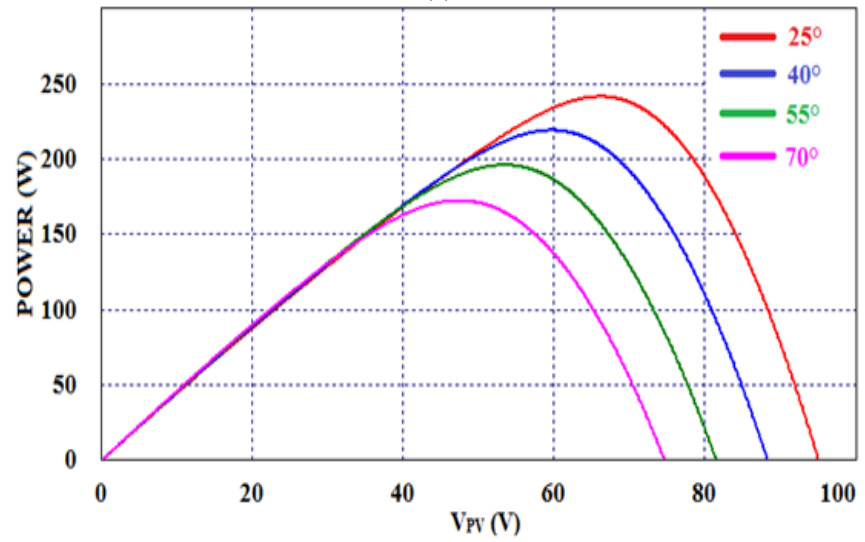

(b)

Fig. 4. Photovoltaic generator characteristics under different level of temperature and at $1000\left(\mathrm{~W} / \mathrm{m}^{2}\right)$ : (a) $\mathrm{I}_{\mathrm{pv}}=\mathrm{f}\left(\mathrm{V}_{\mathrm{pv}}\right)$, (b) $\mathrm{P}_{\mathrm{pv}}=\mathrm{f}\left(\mathrm{V}_{\mathrm{pv}}\right)$

\section{B. Modelling of the wind turbine generator (WTG) system}

In general, a wind turbine generator (WTG) system consists of a wind turbine with blades which takes the energy of the air mass in motion, a synchronous machine with permanent magnets for the electromechanical conversion, a three phase uncontrolled rectifier, which makes the (AC/DC) electric conversion.

\section{a) Modelling of the wind turbine (WT)}

A wind turbine (WT) is a machine that converts wind energy into mechanical energy. The power developed by a (WT) is demonstrated [16] by:

$P_{\text {turbine }}=\frac{1}{2} C_{p}(\beta, \lambda) \rho \pi R^{2} V_{V}^{3}$

Where $\mathrm{R}$ is the radius of the (WT), $\mathrm{V}_{\mathrm{V}}$ is the wind speed, $\rho$ is the air density, $C_{p}(\beta, \lambda)$ is the power coefficient, $\lambda$ is the tip speed ratio and $\beta$ is the pitch angle. In this work $\beta$ is fixed to zero. The tip speed ratio is defined by:

$$
\lambda=\frac{R \Omega_{\text {turbine }}}{V_{V}}
$$

Where $\Omega_{\text {turbine }}$ is the angular velocity of the rotor of the (WT). The curve of the output power of the wind turbine (WT) versus to different level of wind speed is shown in Figure 5.

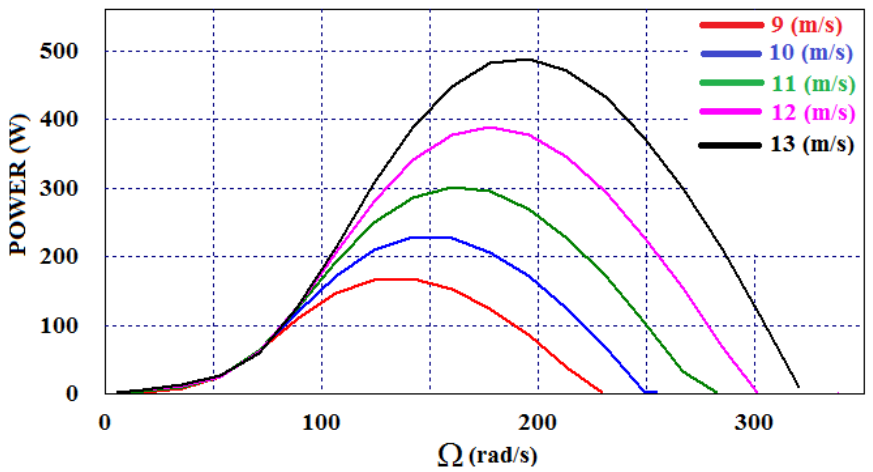

Fig. 5. Output power of the (WT) versus to different level of wind speed

b) Modelling of the permanent magnetic synchronous generator ( $P M S G)$

These types of generators are the most used, in the category of small wind turbine generator (SWTG) for its low cost and simplicity. The mathematical model of the (PMSG) is given [17] by:

$v_{q}=-R_{S} i_{q}-L_{q} \frac{d i_{q}}{d t}+\omega_{e} L_{d} i_{d}+\omega_{e} \lambda_{m}$

$v_{d}=-R_{S} i_{d}-L_{d} \frac{d i_{d}}{d t}+\omega_{e} L_{q} i_{q}$

Where $R_{S}$ is the stator winding resistance; $L_{d}$ and $L_{q}$ are stator inductances in direct and quadrature axis, respectively; $i_{d}$ and $i_{q}$ are the currents in direct and quadrature axis, respectively; $\omega_{\mathrm{e}}$ is the electrical angular speed of the generator; $\lambda_{\mathrm{m}}$ is the amplitude of the flux linkage. The expression for the electromagnetic torque can be described as:

$T_{e m}=\left(\frac{3 P}{2}\right)\left[\left(L_{d}-L_{q}\right) i_{q} i_{d}+i_{q} \lambda_{m}\right]$

Where $P$ is the number of poles pairs. The relation between electrical angular speed $\omega_{\mathrm{e}}$ and mechanical angular speed $\Omega_{\text {turbine }}$ is expressed by:

$\omega_{e}=\frac{P}{2} \Omega_{\text {turbine }}$

c) Modelling of the three phase uncontrolled rectifier

Figure 6 shows the PMSG with a three phase diode rectifier. $R_{S}$ is the stator resistance, $L_{S}$ is the stator inductance of PMSG. The instantaneous voltage (phase a) of (PMSG) are given by [18]:

$V_{a n}=V_{m} \sin (\omega t)$ 
Where, $\mathrm{V}_{\mathrm{m}}$ is the peak value of phase voltage. The dc voltage and current output depend on the generator voltage and current as follows:

$V_{d c}=\frac{3 \sqrt{3}}{\pi} V_{m}=\frac{3 \sqrt{6}}{\pi} \lambda_{m-e f f} P \Omega$

$I_{d c}=\frac{\pi}{\sqrt{6}} I_{a}$

Where $\lambda_{\mathrm{m} \text {-eff }}$ is the amplitude of the flux linkages (Wb). $\mathrm{V}_{\mathrm{dc}}$ and $\mathrm{I}_{\mathrm{dc}}$ are average output voltage and current of the rectifier, and $I_{a}$ is the output current of the generator (phase a).

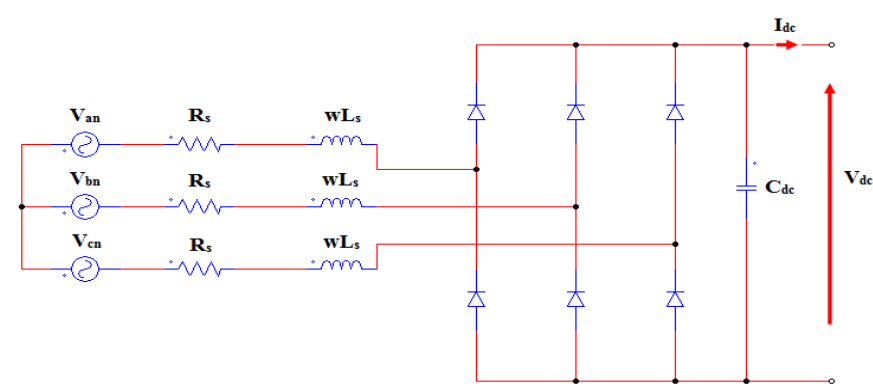

Fig. 6. (PMSG) with three phase diode rectifier

\section{III. (DC-DC) POWER STAGE}

(DC-DC) the power converter is an electronic circuit that converts a source of dc current from one voltage level to another. In this paper, two dc-dc buck converters and a dc-dc boost converter are used in order to achieve a high efficiency of the hybrid system. This section describes the mathematical model and the design of these power converters [19].

\section{A. (DC-DC) Buck converter}

(DC-DC) a buck converter, illustrated in Figure 7 is used in our work as an intermediate between the photovoltaic generator (PVG), wind turbine generator (WTG) and the load to extract the maximum power from these two sources. We can easily deduce the average output voltage and current in the load as [19]:

$\left\{\begin{array}{l}V_{o}=\alpha_{\text {buck }} V_{\text {in }} \\ I_{o}=\left(1 / \alpha_{\text {buck }}\right) I_{L}\end{array}\right.$

With $0<\alpha_{\text {buck }}<1$

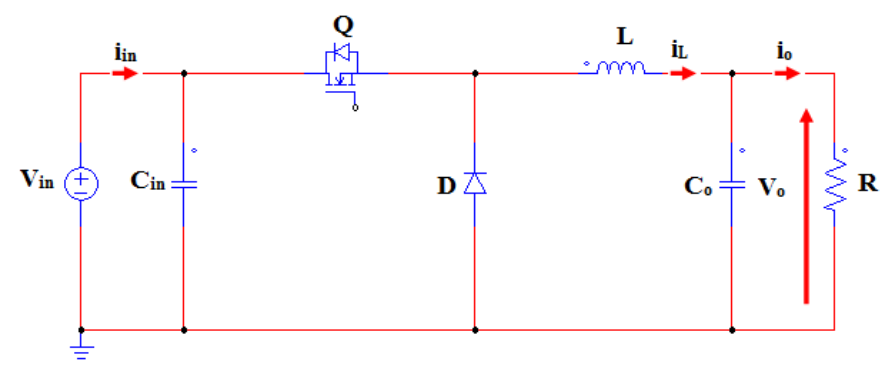

Fig. 7. Basic schema of (dc-dc) buck converter

\section{B. (DC-DC) boost converter}

In this power converter illustrated in Figure 8, the average output voltage is greater than the input voltage. The average output voltage and current in the load are given by [19]:

$\left\{\begin{array}{l}V_{o}=\left(\frac{1}{1-\alpha_{\text {boost }}}\right) V_{\text {in }} \\ I_{o}=\left(1-\alpha_{\text {boost }}\right) I_{L}\end{array}\right.$

With $0<\alpha_{\text {boost }}<1$

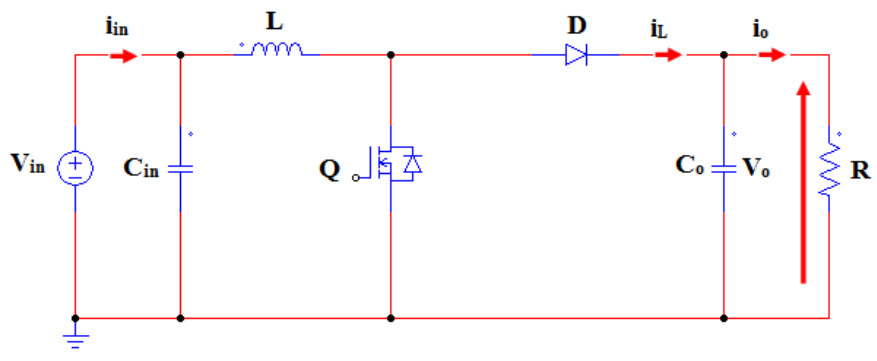

Fig. 8. Basic schema of (dc-dc) boost converter

\section{MODELING OF THE BATTERY BANK}

Different types of battery models are presented in the literature [20]. In this wok the linear model is used as the battery model. This model consists of an ideal battery with open-circuit voltage, $E_{0}$ and an equivalent series resistance, $R_{S} . \mathrm{V}_{\text {batt }}$ represents the terminal voltage of the battery. This terminal voltage can be obtained from the open circuit tests as well as from load tests conducted on a fully charged battery. Figure 9 illustrated the linear model of the battery.

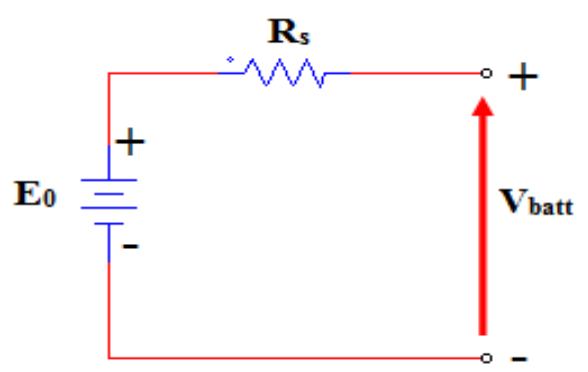

Fig. 9. Basic schema of the battery linear model

\section{CONTROL StRATEGIES OF THE (PVG)/(WTG) HYBRID SYSTEM}

A. Maximum power tracking strategies the $(P V G) /(W T G)$ hybrid system

1) $\operatorname{MPPT}(P \& O)$ Technique:

Perturb and Observe (P\&O) is one of the MPPT techniques. This method uses the (voltage/current) to compute maximum power. As its name indicates, this method works by perturbing and observing the impact of the system regulation on the output power of the renewable energy sources [21]. Figure 10 shows (P\&O) algorithm flowchart. 


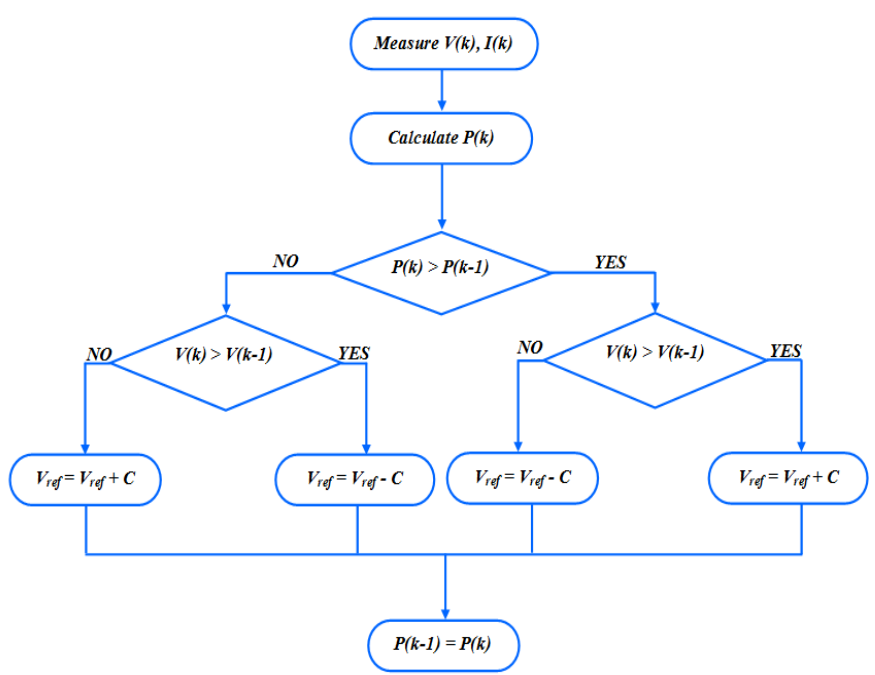

Fig. 10. (P\&O) algorithm flowchart

2) Maximum tracking control strategy for the (WTG):

The aim of the MPPT technique is to set the power coefficient $\mathrm{C}_{\mathrm{p}}$ to its maximal value. $\mathrm{C}_{\mathrm{p}}=\mathrm{C}_{\mathrm{p} \max }$, corresponding to the $\lambda_{\text {opt }}[22-23]:$

$$
\Omega_{o p t}=\frac{\lambda_{\text {opt }}}{R} V_{V}
$$

(18) We deduce the maximum value of the power of the (WTG) as:

$$
P_{\max }=K_{\text {opt }} \Omega_{\text {turbine }}{ }^{3}
$$

The optimal torque allowing the (MPPT) is given by:

$T_{\text {em_ref }}=K_{\text {opt }} \Omega_{\text {turbine }}{ }^{2}$

Where

$$
K_{o p t}=0.5 \rho \pi R^{2}\left(\frac{R}{\lambda_{o p t}}\right)^{3} C_{p \max }
$$

The dc-dc buck converter is used to track the maximum power of the PMSG at any wind speed. In this work the (P\&O) algorithm is used to generate a reference current $I_{\text {ref }}$, which is compared to the measured battery current $\mathrm{I}_{\text {batt }}$. After that, the error between $\mathrm{I}_{\text {ref }}$, and $\mathrm{I}_{\text {batt }}$ is passed through a PI controller. The output of the PI controller is added to the measured voltage of the combination of the two sources $V_{\text {hybrid }}$ and divided by the measured output voltage of the uncontrolled rectifier $\mathrm{V}_{\mathrm{dc}}$ to generate the duty cycle. The duty cycle generated is used to produce the right PWM pulse for the switch of the dc-dc buck converter. Finally, the PMSG will work under the desired condition. In the other hand, when the wind reaches a certain speed, the available wind power can exceed the nominal power of the (WTG), which can impair the correct operation of the PMSG and the dc-dc buck converter. To limit the power value, the author in [9] has used a technique which consists of imposing a limit value of power and was compared it to the measured power on the battery side to set the reference value of power. In our work, we imposed a limit current which corresponds to the limiting power, in our case $550(\mathrm{~W})$. This value was compared with the value of the current generated by the $(\mathrm{P} \& \mathrm{O})$ algorithm to impose the final reference current value that was used in our control strategy.

The (MPPTCC) diagram of the wind turbine generator (WTG) system is shown in Figure 11.

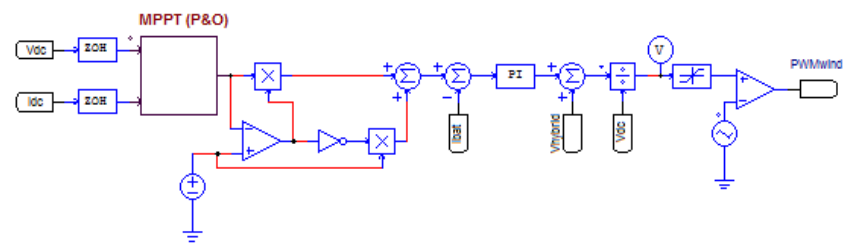

Fig. 11. The MPPT strategy control of the wind turbine generator (WTG)

3) The Proposed MPPT Sliding Mode Control(MPPTSMC) approach:

The aim of this section is to develop a novel approach to extract the maximum power from the photovoltaic generator using a sliding mode control (SMC).

Sliding mode control (SMC) is a nonlinear control solution and a variable structure control (VSC). It is a technique that maintains the system trajectory along a particular surface, which is commonly called a sliding surface. The design of the control can be realised in three main steps very dependent on each other [24]:

- The choice of the surface.

- The establishment of the existence of convergence conditions.

- Determining of the control law.

In this section, we are interested in the synthesis of a sliding mode control using a reference voltage $\mathrm{V}_{\text {ref }}$ provided by an MPPT ( $\mathrm{P} \& \mathrm{O})$ algorithm to extract the maximum power from the photovoltaic generator. The sliding surface assures that the sliding movement is reached and regulates the output voltage of the dc-dc buck converter at desired value $\mathrm{V}_{\text {desired }}=24 \mathrm{~V}$.

After determined $\mathrm{V}_{\text {ref }}$, the (SMC) algorithm calculate the difference between the obtained photovoltaic voltage $\mathrm{V}_{\mathrm{PV}}$ and the $\mathrm{V}_{\text {ref }}$ and then, via the buck converter force the photovoltaic generator to operate at the reference voltage $\mathrm{V}_{\text {ref }}$ and therefore at the maximum power zone [25].

$$
\begin{aligned}
& S\left(V_{\text {hybrid }}, U, \psi\right)=V_{P V}-V_{\text {ref }}+K \psi \\
& \dot{\psi}=V_{\text {hybrid }}-V_{\text {desired }}, \psi(0)=0
\end{aligned}
$$

Where $V_{\text {desired }}$ desired output voltage of the dc-dc buck $(24 \mathrm{~V}) . \mathrm{K}$ is a positive constant and $\mathrm{V}_{\text {hybrid }}$ is the voltage value of the combination of the two sources. 
The control law for this case is described by:

$$
U= \begin{cases}1 & S\left(V_{\text {hybrid }}, U, \psi\right) \geq 0 \\ 0 & S\left(V_{\text {hybrid }}, U, \psi\right)<0\end{cases}
$$

Indeed, if $S \geq 0$ then the operating point is to the right of the reference voltage $\mathrm{V}_{\text {ref }}$, the command must move it to the left. This is possible, if $U=1$. On the other hand, if $S<0$ then the operating point is on the left of the reference voltage $V_{\text {ref }}$, the command must move it to the right. This is possible if $\mathrm{U}=0$.The (MPPTSMC) diagram of the photovoltaic generator (PVG) system is shown in Figure 12.

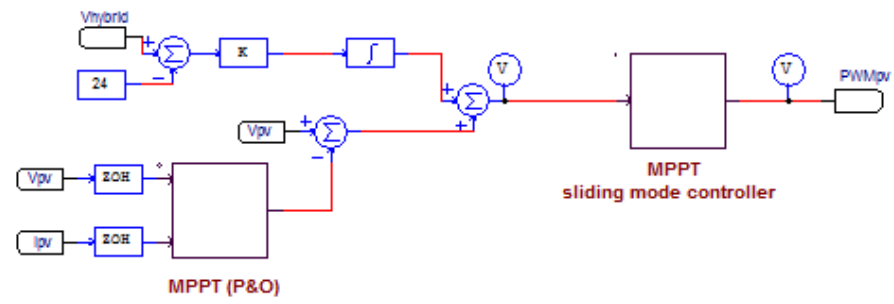

Fig. 12. The MPPT strategy control of the photvoltaic generator (PVG)

\section{4) Boost output votage sliding mode control:}

We propose in this section, a control strategy of the output voltage of the hybrid system. Indeed, in the most industrial applications supplied by a renewable energy source, such as water pumping, the load must be powered by a constant voltage. In our work, we intercalated a dc-dc boost converter, in cascade with the output of the combination of the two sources, controlled by a sliding mode controller (SMC) to reach the desired output voltage.

The control law for this case is described by:

$U_{1}= \begin{cases}1 & S_{1} \geq 0 \\ 0 & S_{1}<0\end{cases}$

Where $S_{1}$ is the sliding surface.

The following values were considered, $\mathrm{x}_{1}=\mathrm{I}_{\mathrm{Hybrid}}$ and $\mathrm{x}_{2}=\mathrm{V}_{\text {boost }}$. The goal here is to reach the reference voltage value, $\mathrm{V}_{\text {boost_ref }}$ :

$x_{2}=V_{\text {boost_ref }}$

Based on the theory of sliding mode proposed in [26], we can define the sliding mode surface as follows:

$S_{1}=x_{1}-I_{\text {Lref }}=0$
To impose $S_{1}=0$, we will use the control signal $U_{1}$ proposed in [26]:

$U_{1}=\frac{1}{2}\left(1-\operatorname{sign}\left(S_{1}\right)\right)$

The (SMC) diagram of the (dc-dc) boost converter is shown in Figure 13.

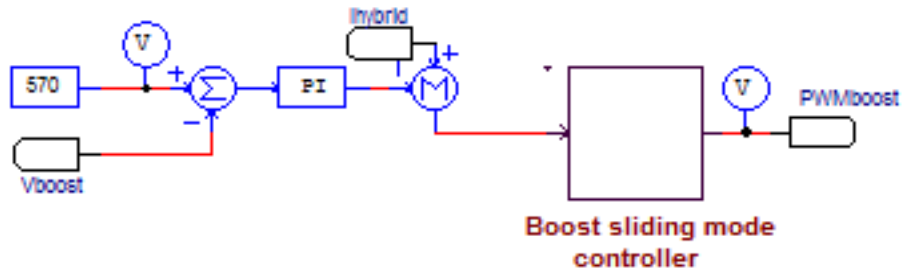

Fig. 13. The (SMC) of the (dc-dc) boost converter

\section{Simulation Results AND Discussion}

In order to validate the proposed strategies of power control and show its effectiveness, a simulation of the global system described in Figure 14 was carried out using PSIM software [27]. The (PVG) consist of four photovoltaic modules of Kaneka k60 of $60(\mathrm{~W})$ [28] are connected in parallel, and a combined block is formed with dc-dc buck power converter. In the other hand, the AIR X 400W small (WTG) [29] coupled with (PMSG), a three phase uncontrolled rectifier and the dcdc buck converter. Technical parameters of the (PVG) and the (WTG) are shown in Table1, Table 2 respectively.

TABLE I. KaneKa K60 VALUES USED WITH THE PSIM SOFTWARE TOOL (AT STANDARD TEST CONDITIONS: $1000 \mathrm{~W} / \mathrm{M} 2 \& 25^{\circ} \mathrm{C}$ )

\begin{tabular}{|l|l|}
\hline Parameters & Values \\
\hline Maximum Power $\boldsymbol{P}_{\max }$ & $60 \mathrm{~W}(+10 /-5 \%)$ \\
\hline Cells per Module & 108 \\
\hline Voltage at $\boldsymbol{P}_{\max }$ & $67 \mathrm{~V}$ \\
\hline Current at $\boldsymbol{P}_{\max }$ & $0.91 \mathrm{~A}$ \\
\hline Open Circuit Voltage $\left(\boldsymbol{V}_{\boldsymbol{o c}}\right)$ & $94 \mathrm{~V}$ \\
\hline Short-Circuit Current $\left(\boldsymbol{I}_{\text {sc }}\right)$ & $1.19 \mathrm{~A}$ \\
\hline Shunt Resistance $\boldsymbol{R}_{\text {sh }}$ & $4 \mathrm{ohm}$ \\
\hline Series Resistance $\boldsymbol{R}_{\boldsymbol{s}}$ & $0.16 \mathrm{ohm}$ \\
\hline
\end{tabular}

TABLE II. TECHNICAL SPECIFICATIONS OF THE AIR X Wind TURbine USED WITH THE PSIM SOFTWARE TOOL

\begin{tabular}{|l|l|}
\hline Parameters & Values \\
\hline Rotor Diameter & $46 \mathrm{in}(1.15 \mathrm{~m})$ \\
\hline Weight & $13 \mathrm{lb}(5.85 \mathrm{~kg})$ \\
\hline Start Up Wind Speed & $15.6 \mathrm{mph}(7.5 \mathrm{~m} / \mathrm{s})$ \\
\hline Voltage & $24 \mathrm{VDC}$ \\
\hline Rated Power & $386 \mathrm{watts}$ at $28 \mathrm{mph}(12.5 \mathrm{~m} / \mathrm{s})$ \\
\hline Base rotational speed & $1700 \mathrm{rpm}$ \\
\hline Initial rotational speed & $500 \mathrm{rpm}$ \\
\hline Moment of inertia & $0.001 \mathrm{~m} \mathrm{Kg} \cdot \mathrm{m}^{2}$ \\
\hline
\end{tabular}



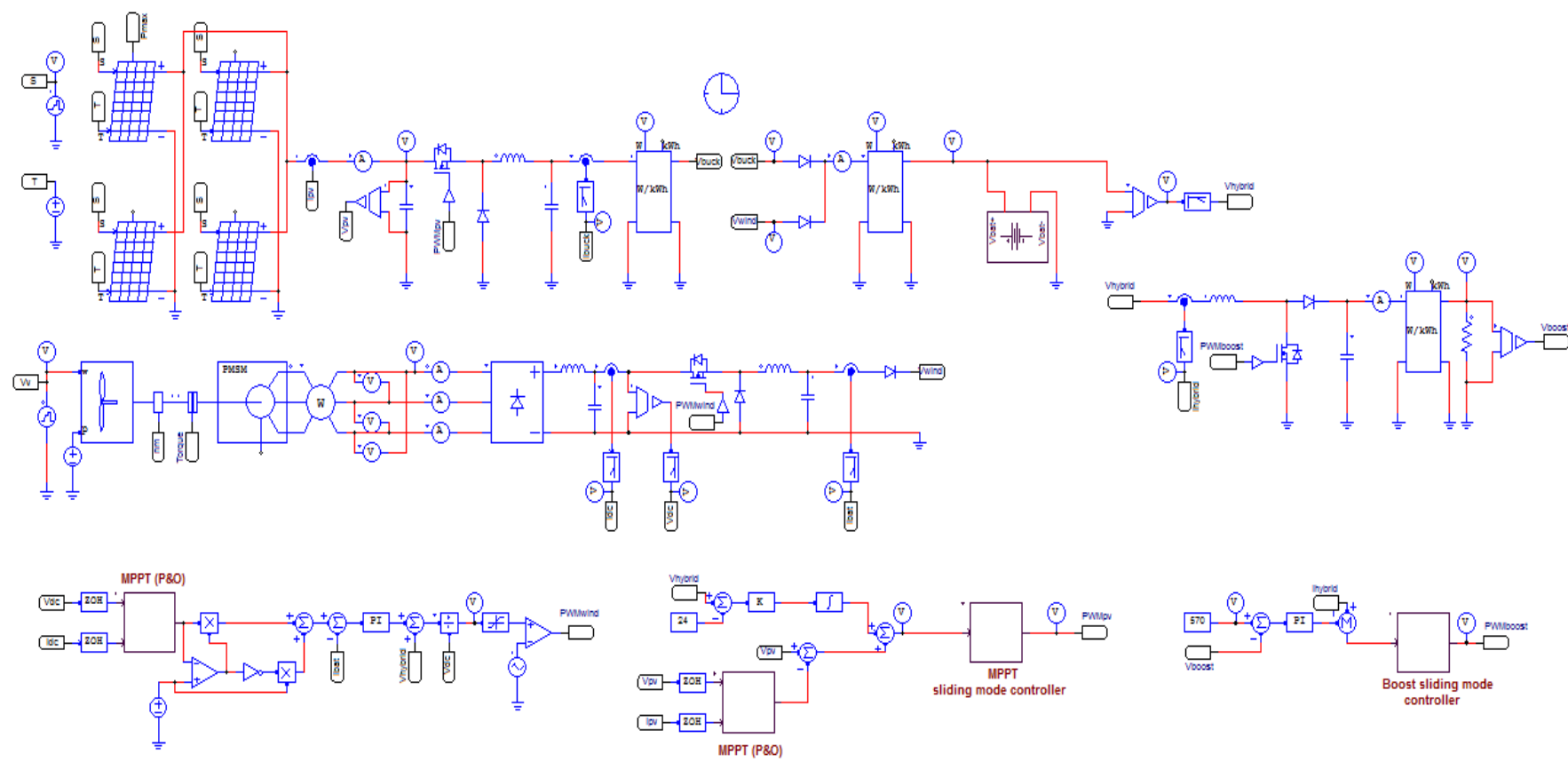

Fig. 14. Simulation bloc of the (PVG) / (WTG) hybrid system

1) Simulation results of the photovoltaic generator (PVG) system

The photovoltaic irradiation level starts from $\left(800 \mathrm{~W} / \mathrm{m}^{2}\right)$, then increases to $\left(1000 \mathrm{~W} / \mathrm{m}^{2}\right)$, after that decreases to $\left(650 \mathrm{~W} / \mathrm{m}^{2}\right)$, and reach the value of $900 \mathrm{~W} / \mathrm{m}^{2}$ finally. In this work the temperature is fixed to the value $25^{\circ} \mathrm{C}$. Figure 15 shows the photovoltaic sunshine profile.

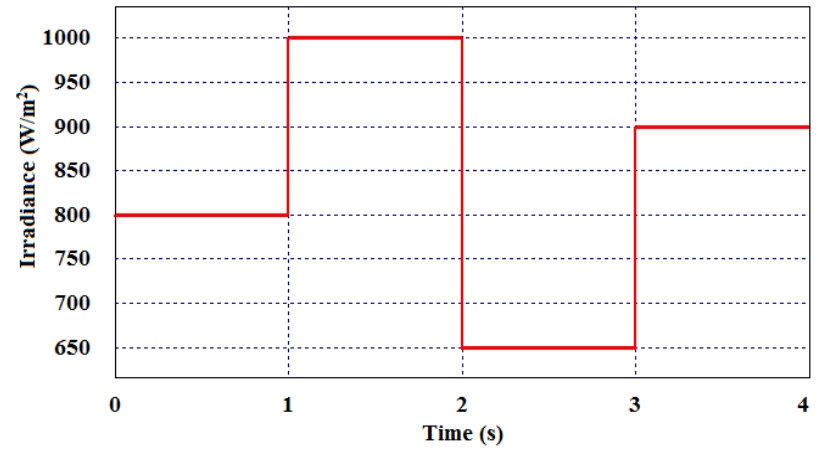

Fig. 15. Irradiance profile

The dc-dc buck converter is used here as a matching stage, it helps to extract the maximum power from the photovoltaic panel and ensure a good use of the power energy. The parameters design of the dc-dc buck converter used in the (PVG) system is illustrated in Table 3.

Figure 16 shows the output voltage of the (PVG) under different levels of irradiance, and we can see that its value is nearly equal to the output voltage $\left(\mathrm{V}_{\mathrm{mpp}}\right)$ of the photovoltaic panel at the maximum power point and the value is about $67(\mathrm{~V})$. The output voltage of the buck converter used in the
(PVG) is illustrated in Figure 17, and we can notice that the value is nearly stable at $24 \mathrm{~V}$.

TABLE III. DESIGN OF THE BUCK CONVERTER FOR THE (PVG) SYSTEM

\begin{tabular}{|l|l|l|}
\hline Symbol & Actual Meaning & Value \\
\hline$V_{\text {in }}$ & Input voltage & $67 \mathrm{~V}$ \\
\hline$V_{\text {out }}$ & Output voltage & $24 \mathrm{~V}$ \\
\hline$D$ & Duty cycle & 0.358 \\
\hline L & Filter inductance & $27 \mu \mathrm{H}$ \\
\hline C & Filter capacitance & $470 \mu \mathrm{F}$ \\
\hline$I_{\text {out }}$ & Maximum output current & $10.05 \mathrm{~A}$ \\
\hline
\end{tabular}

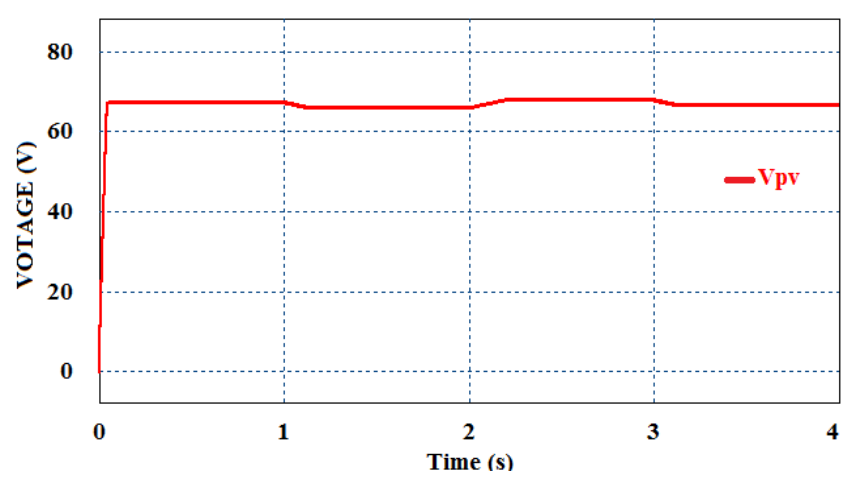

Fig. 16. The output voltage of the (PVG) 


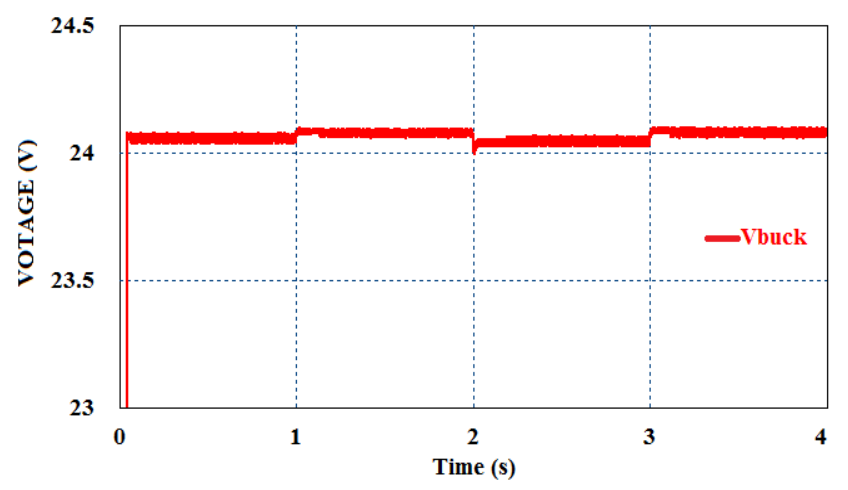

Fig. 17. The output voltage of the dc-dc buck converter used in (PVG) system

At the period of simulation between $3(\mathrm{~s})$ and $4(\mathrm{~s})$ of Figure 15 , the photovoltaic irradiance is fixed at $900\left(\mathrm{~W} / \mathrm{m}^{2}\right)$. At this condition, the output current delivered from the (PVG) is 3.24(A) as shown in Figure 18 and the output current of the dcdc buck converter is equal to 8.69(A) as shown in Figure 19.

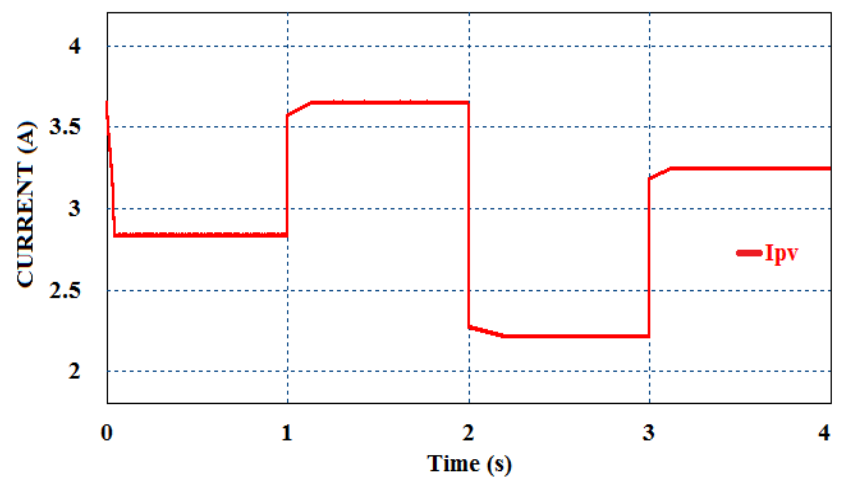

Fig. 18. The output current of the (PVG)

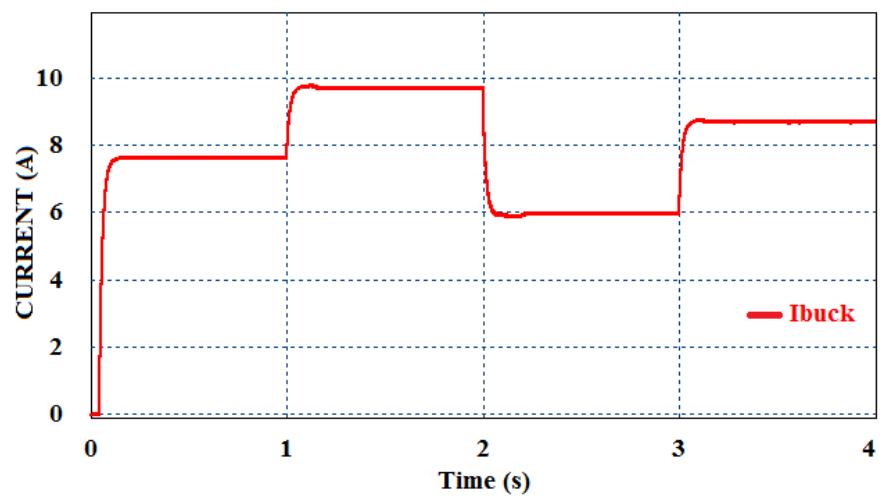

Fig. 19. The output current of the dc-dc buck converter in (PVG) system

Figure 20 shows the waveform of the output powers of the (PVG) and the dc-dc buck converter for step change of irradiance from $800\left(\mathrm{~W} / \mathrm{m}^{2}\right)$ to $1000\left(\mathrm{~W} / \mathrm{m}^{2}\right)$ to $650\left(\mathrm{~W} / \mathrm{m}^{2}\right)$, and then to $900\left(\mathrm{~W} / \mathrm{m}^{2}\right)$.

The pursuit of maximum power point is good and without oscillation. The yield is maximal and the efficiency of the
(PVG) system is more than $95 \%$ as shown in Figure 21. From the simulation results, we can notice, the robustness of the (MPPTSMC) against the variation of photovoltaic sunshine.

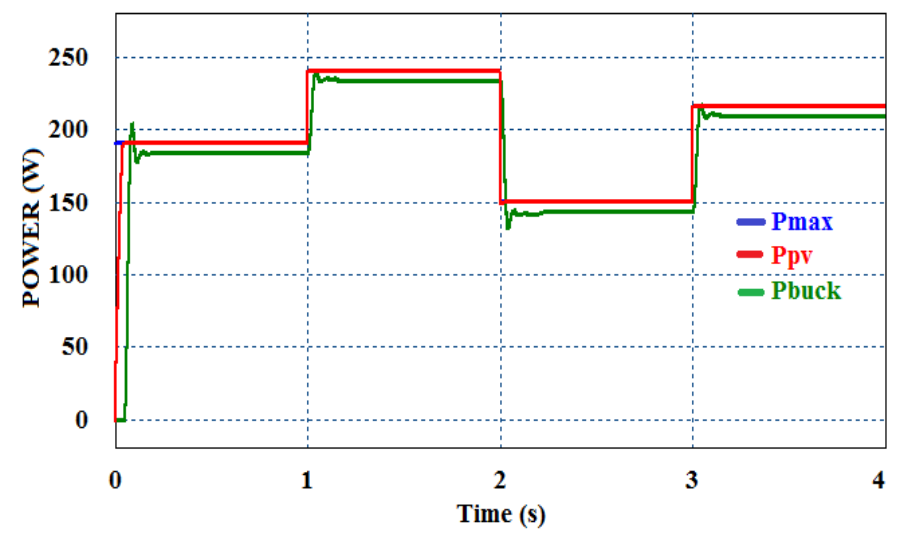

Fig. 20. Outputs powers of the (PVG) system

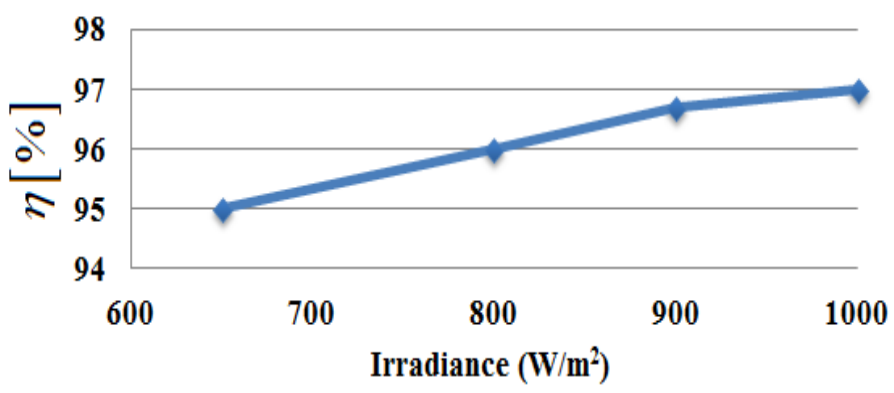

Fig. 21. The efficiency of the (PVG) system

2) Simulation results of the wind turbine generator system For the wind speed, the changing profile is shown in Figure 22. It evolves from a value of $11(\mathrm{~m} / \mathrm{s})$ to $12(\mathrm{~m} / \mathrm{s})$, then to $10.5(\mathrm{~m} / \mathrm{s})$ and finally it increases to a value of 12.5 $(\mathrm{m} / \mathrm{s})$.The dc-dc buck converter is used here as a matching stage, it helps to extract the maximum power from the wind turbine generator (WTG). The parameters design of the dc-dc buck converter used in the (WTG) is illustrated in Table 4.

TABLE IV. DESIGN OF THE BUCK CONVERTER FOR THE (WTG) SYSTEM

\begin{tabular}{|c|c|c|}
\hline Symbol & Actual Meaning & Value \\
\hline$V_{\text {in }}$ & Input voltage & $67.74 \mathrm{~V}$ \\
\hline$V_{\text {out }}$ & Output voltage & $24 \mathrm{~V}$ \\
\hline$D$ & Duty cycle & 0.354 \\
\hline L & Filter inductance & $50 \mu \mathrm{H}$ \\
\hline C & Filter capacitance & $470 \mu \mathrm{F}$ \\
\hline$I_{\text {out }}$ & Maximum output current & $16.04 \mathrm{~A}$ \\
\hline
\end{tabular}




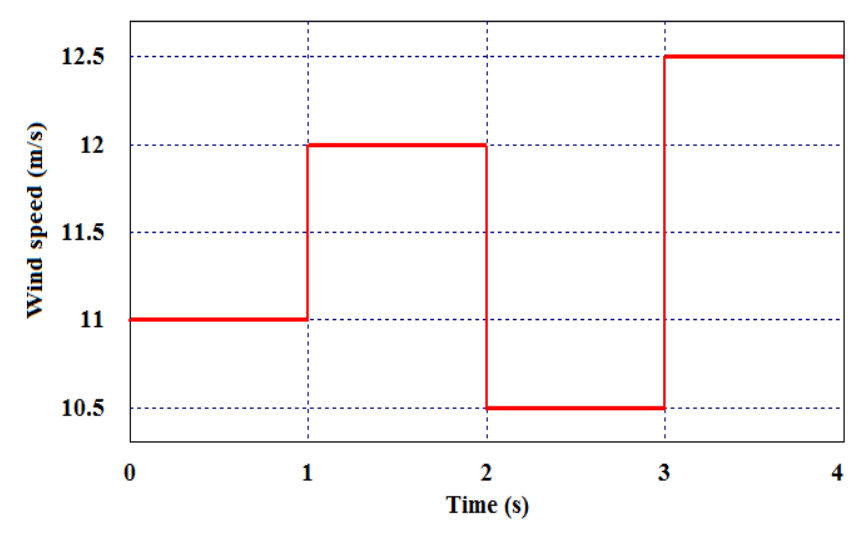

Fig. 22. Wind speed profile

Figure 23 shows the variations of the Wind turbine power coefficient $C_{P}$ under different levels of wind speed. The variation of the tip speed ratio under different levels of wind speed is illustrated in Figure 24.

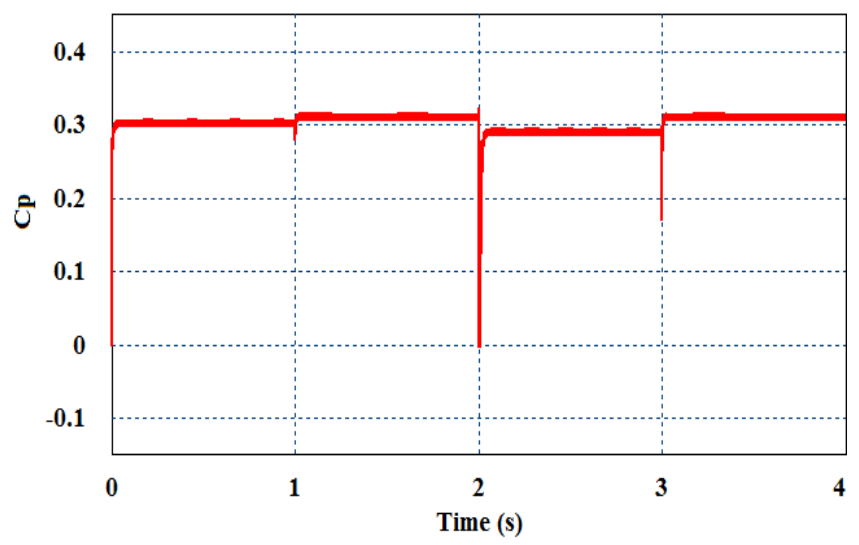

Fig. 23. Power coefficent $C_{P}$ of the (WTG)

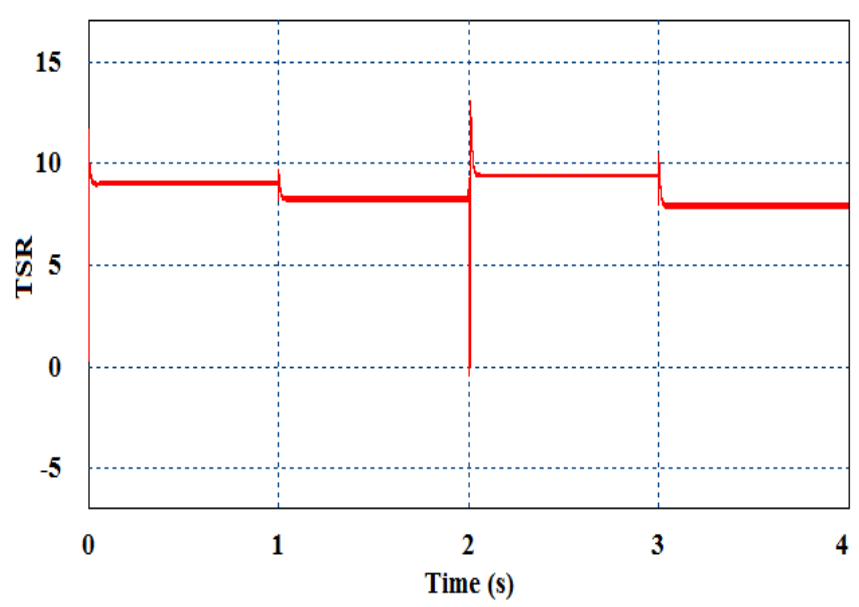

Fig. 24. Tip speed ratio (TSR) of the (WTG)

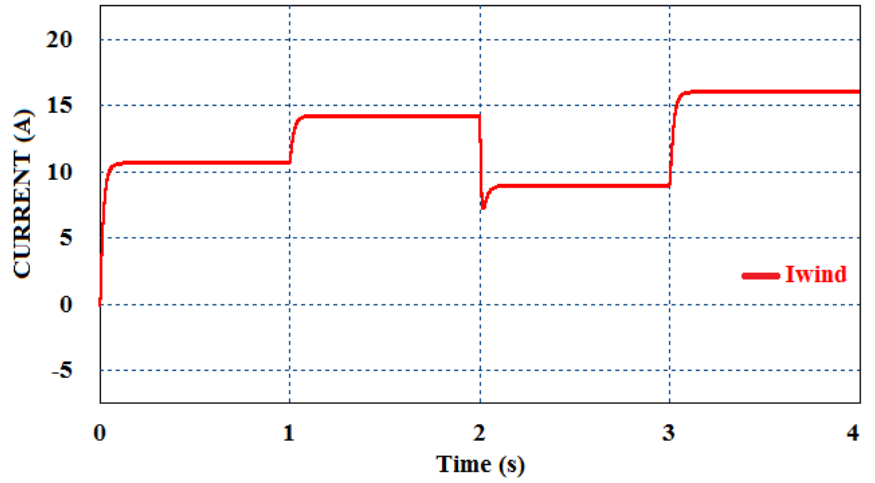

Fig. 25. The output current of the dc-dc buck converter used in (WTG) system

At the period of simulation between 3(s) and 4(s) of Figure 22 , the wind speed is fixed at $12.5(\mathrm{~m} / \mathrm{s})$. At this condition, the output current of the dc-dc buck converter is equal to 16.02(A) as shown in Figure 25.

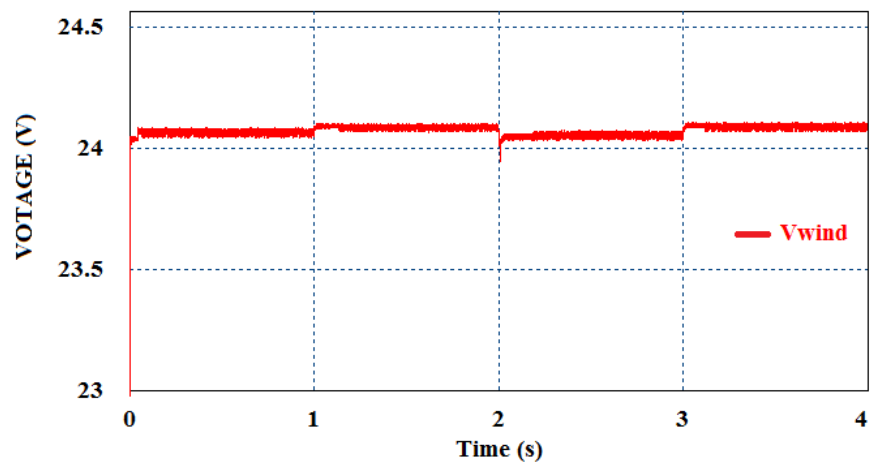

Fig. 26. The output voltage of the dc-dc buck converter used in (WTG) system

The output voltage of the buck converter used in the (WTG) is illustrated in Figure 26, and we can notice that the value is nearly stable at $24(\mathrm{~V})$.

Figure 27 shows the waveform of the output powers of the (WTG) and the dc-dc buck converter for step change of wind speed from $11(\mathrm{~m} / \mathrm{s})$ to $12(\mathrm{~m} / \mathrm{s})$ to $10.5(\mathrm{~m} / \mathrm{s})$, and then to 12.5 $(\mathrm{m} / \mathrm{s})$.

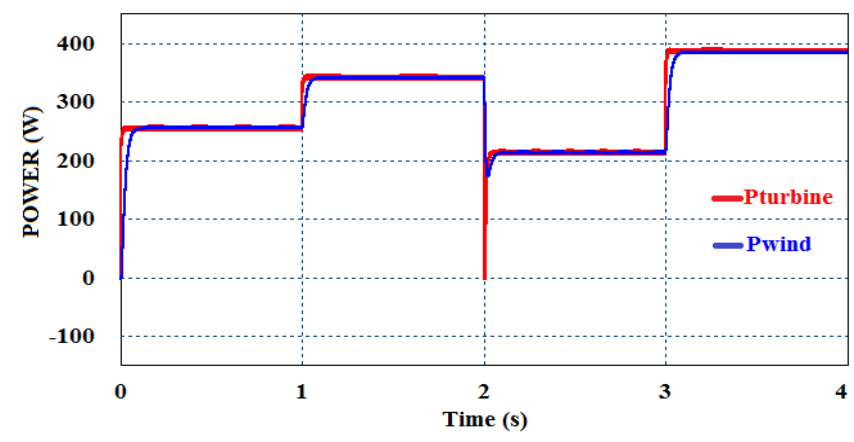

Fig. 27. Output powers of the (WT) and the dc-dc buck converter used in (WTG) system 
The pursuit of maximum power point is good and without oscillation. The yield is maximal and the efficiency of the (WTG) system is more than $98 \%$ as shown in Figure 28. From the simulation results, we can notice, the robustness of the (MPPTCC) against the variation of wind speed.

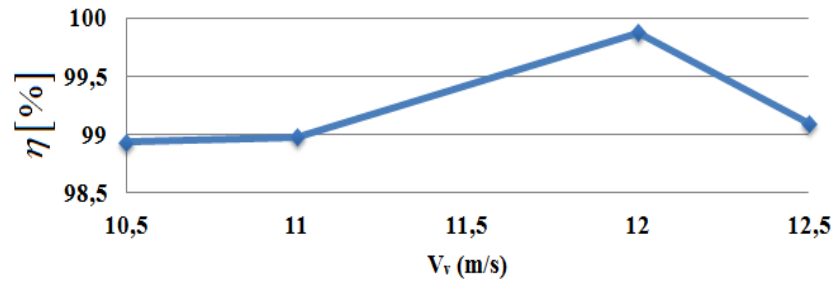

Fig. 28. Efficiency of the (WTG) system

3) Simulation results of the hybrid power system

The output voltage which is obtained from the (PVG)/(WTG) hybrid system, is illustrated in Figure 29. We can notice that the output voltage $\mathrm{V}_{\text {hydrid }}$ of the combined sources is equal to the output voltages of the two buck converters used in (PVG) and (WTG). The output voltage $\mathrm{V}_{\text {hydrid }}$ of the combined sources is nearly stable at $24(\mathrm{~V})$.

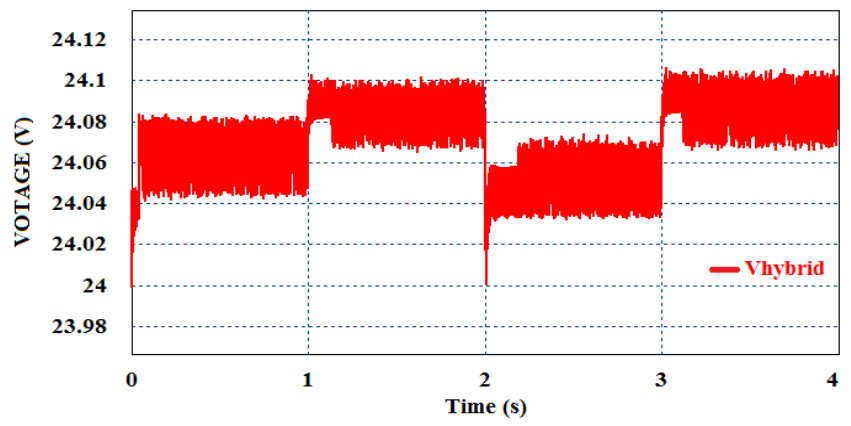

Fig. 29. Output voltage the combined sources

Figure 30 point out the simulation results of the output current of combined sources $\mathrm{I}_{\text {hybrid. }}$. We can deduce that when the climate factors changes, the output current $\mathrm{I}_{\text {hybrid }}$ is less than 30(A) and more than 5(A).

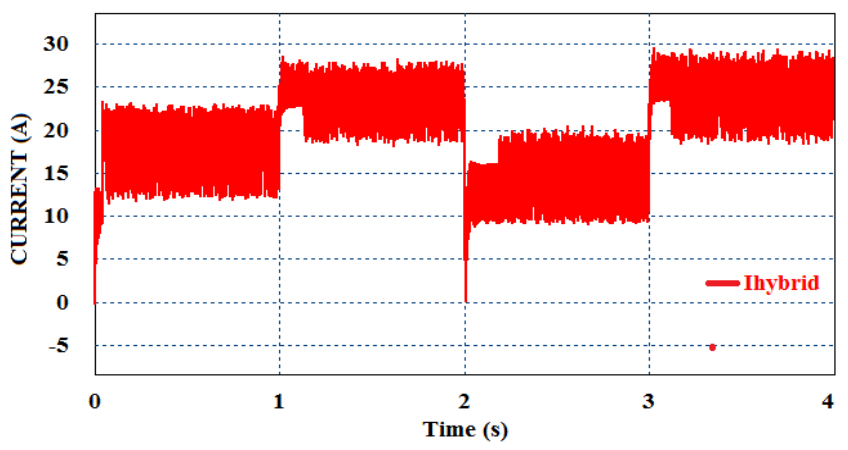

Fig. 30. Output currents the combined sources

Figure 31 shows the simulation results of the output powers which is obtained from the (PVG)/(WTG) hybrid system for varying sunshine values $\left(800 \mathrm{~W} / \mathrm{m}^{2}, 1000 \mathrm{~W} / \mathrm{m}^{2} 650 \mathrm{~W} / \mathrm{m}^{2}\right.$ and $\left.900 \mathrm{~W} / \mathrm{m}^{2}\right)$ and varying wind speed $(11 \mathrm{~m} / \mathrm{s}, 12 \mathrm{~m} / \mathrm{s}, 10.5 \mathrm{~m} / \mathrm{s}$ and $12.5 \mathrm{~m} / \mathrm{s}$ ). We can notice that, the hybrid power is equal to the sum of the two powers delivered by the two sources.

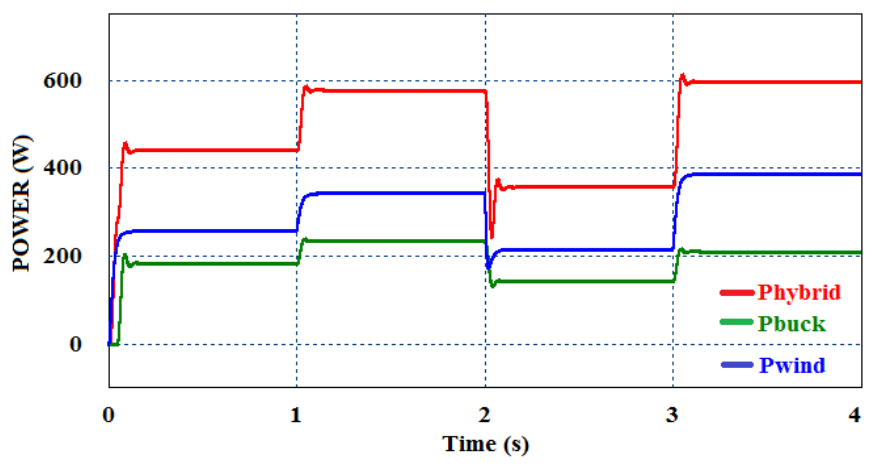

Fig. 31. Output powers of the (PVG)/(WTG) hybrid system

4) Simulation results of the the dc-link boost output voltage control

The dc-link voltage control is based on (PI) controller and the current loop is based on the sliding mode control (SMC). The Proportional Integral controller is having the following parameters: the gain $\mathrm{K}=0.01$ and the time constant $\mathrm{T}=0.0001 \mathrm{~s}$. The parameters design of the dc-dc boost converter used in this paper is illustrated in Table 5.

TABLE V. DESIGN OF THE BoOst CONVERTER

\begin{tabular}{|l|l|l|}
\hline Symbol & Actual Meaning & Value \\
\hline$V_{\text {in }}$ & Input voltage & $24 \mathrm{~V}$ \\
\hline$V_{\text {out }}$ & Output voltage & $570 \mathrm{~V}$ \\
\hline D & Duty cycle & 0.957 \\
\hline L & Filter inductance & $2.7 \mu \mathrm{H}$ \\
\hline C & Filter capacitance & $47 \mu \mathrm{F}$ \\
\hline$I_{\text {out }}$ & Maximum output current & $0.965 \mathrm{~A}$ \\
\hline
\end{tabular}

Figure 32 illustrates the average output current of the dc-dc boost converter, which is stable at the value of $0.965(\mathrm{~A})$. At the end of the simulation, results have confirmed the utility of the (SMC) approach. The output voltage of the dc-dc boost converter reaches the reference value after $0.043(\mathrm{~s})$ and stabilises at $570(\mathrm{~V})$ as shown in Figure 33.

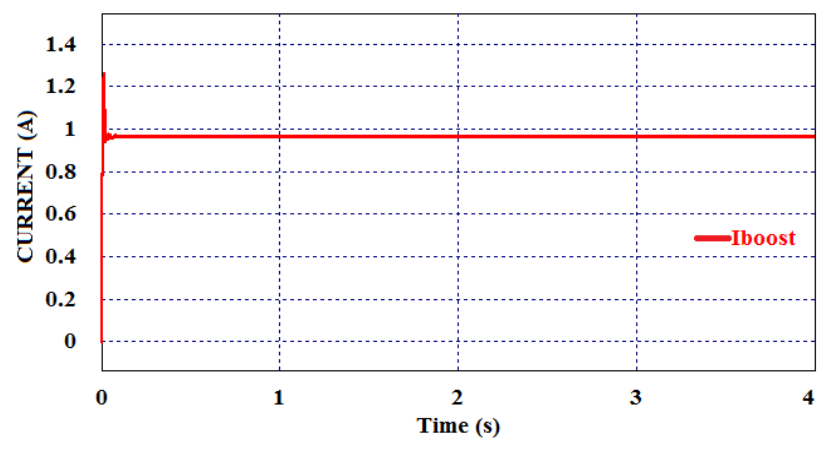

Fig. 32. The output current of the dc-dc boost converter 


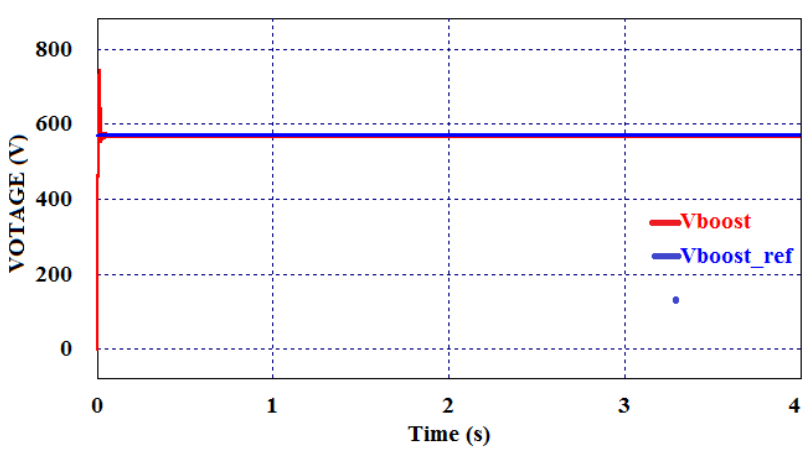

Fig. 33. The output voltage of the dc-dc boost converter

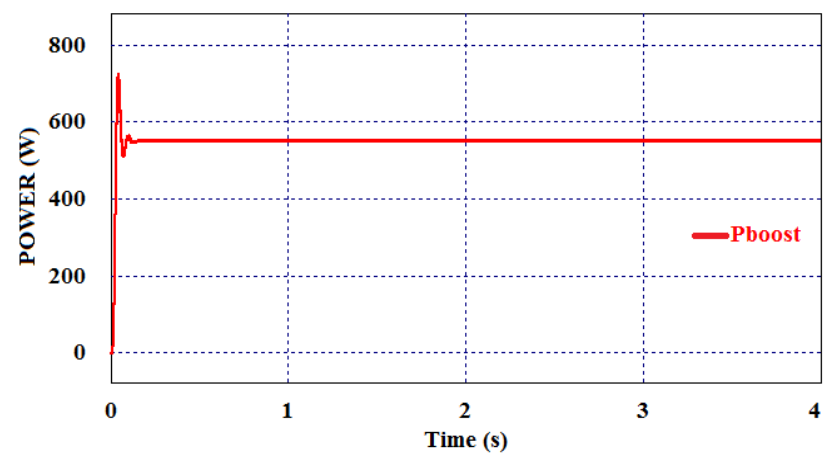

Fig. 34. The output power of the dc-dc boost converter

In another hand, the average output power $\mathrm{P}_{\text {boost }}$ value at the output of the dc-dc boost converter is equal to $547.89(\mathrm{~W})$ as shown in Figure 34. From this we can deduce, that the specifications of the design are respected.

\section{CONCLUSION}

In this paper, the modeling and simulation of standalone (PVG)/(WTG) hybrid power generation system has been proposed by integrating a power electronic converters to permit the good exploitation of this new electricity production unit. The proposed hybrid power system has been implemented under PSIM environment.

A control strategy based on MPPT sliding mode control (MPPTSMC) using the (P\&O) algorithm was developed in order to control the output power of the photovoltaic unit, which comprises a photovoltaic generator (PVG), a dc-dc buck converter that is able to step-down the output load voltage. In another hand, MPPT based on current control (MPPTCC) is used for the wind turbine generator (WTG). In order to control the dc-link voltage at desired and stable value, a dc-dc boost converter is intercalated, in cascade with the output of the combination of the two sources and a sliding mode controller (SMC) was used to obtain the desired output voltage. The configuration proposed in this article plays the role of a small unit of energy production and represent a good solution for standalone applications.

In the future work, we will try to integrate the proposed architecture studied in this paper, in water pumping station intended for rural areas.

\section{REFERENCES}

[1] Andre Malheiro, Pedro M. Castro, Ricardo M. Lima, and Ana Estanqueiro, "Integrated sizing and scheduling of wind/PV/diesel/battery isolated systems", Renewable Energy, Vol. 83, pp. 646-657, April 2015.

[2] M. H. Nehrir, C. Wang, K. Strunz, H. Aki, R. Ramakumar, J. Bing, Z. Miao, and Z. Salameh, "A review of Hybrid Renewable/Alternative Energy Systemsfor Electric Power Generation: Configurations, Control, and Applications", IEEE Transactions On Sustainable Energy,Vol .2 , No .4, pp . 392-403, November 2011.

[3] S. Aissou, D. Rekioua, N. Mezzai, T. Rekioua and S. Bacha, "Modeling and control of hybrid photovoltaic wind power system with battery storage", Energy Conversion and Management ,Vol .89, pp . 615-625, October 2014.

[4] Danvu Nguyen and Goro Fujita, "Analysis of sensorless MPPT method for hybrid PV-Wind system using DFIG Wind Turbines", Sustainable Energy, Grids and Networks, Vol .5, pp . 50-57, November 2015.

[5] Jayalakshmi N. S and D. N. Gaonkar, "Operation of Grid Integrated Wind/PV Hybrid System with Grid Perturbations", International Journal Of Renewable Energy Research, IJRER, Vol .5, No .4, pp . 1106-1111, November 2015.

[6] Dezso Sera, Member, Laszlo Mathe, Tamas Kerekes, Sergiu Viorel Spataru and Remus Teodorescu, "On the Perturb-and-Observe and Incremental Conductance MPPT Methods for PV Systems", IEEE Journal Of Photovoltaics, Vol. 3, No. 3, pp. 1070-1078, July 2013.

[7] A. Zegaoui, M. Aillerie, P. Petit, J.P. Sawicki, J.P. Charles and A.W. Belarbi, "Dynamic behaviour of PV generator trackers under irradiation and temperature changes", Solar Energy, Vol.89, pp 2953-2964, Septembre 2011.

[8] Dipesh Kumar, and Kalyan Chatterjee, A review of maximum power point tracking algorithms for wind energy systems, Renewable and Sustainable Energy Reviews, Vol. 55:957-970, March 2016.

[9] Adam Mirecki, Xavier Roboam and Frdric Richardeau. Architecture Complexity and Energy Efficiency of Small Wind Turbines. IEEE Transactions on Industrial Electronics, 2007, Vol.54 (1), pp.660 - 670.

[10] Emilio Mamarelis, Giovanni Petrone, and Giovanni Spagnuolo, "Design of a Sliding-Mode-Controlled SEPIC for PV MPPT Applications", IEEE Transactions On Industrial Electronics, Vol. 61, No. 7, pp. 3387-3398, JULY 2014.

[11] Reham Haroun, Angel Cid-Pastor, Abdelali El Aroudi, and Luis Martinez-Salamero, "Synthesis of Canonical Elements for Power Processing in DC Distribution Systems Using Cascaded Converters and Sliding-Mode Control”, IEEE Transactions On Power Electronics, Vol. 29, No. 3, pp. 1366-1381, March 2014.

[12] Chen-Chi Chu and Chieh-Li Chen, "Robust maximum power point tracking method for photovoltaic cells: A sliding mode control approach", Solar Energy, Vol. 83, pp. 1370-1378, March 2009.

[13] H. Afghoul, D. Chikouche, F. Krim and A. Beddar, "A novel implementation of MPPT sliding mode controller for PV generation systems", EuroCon 2013, Zagreb, Croatia, pp. 789-794, 1-4 July 2013.

[14] M. G. Villalva, et al., "Comprehensive Approach to Modeling and Simulation of Photovoltaic Arrays," Power Electronics, IEEE Transactions on, vol. 24, pp. 1198-1208, 2009.

[15] G. Walker, "Evaluating MPPT converter topologies using a MATLAB PV model," Journal of Electrical \& Electronics Engineering, Australia, vol. 21, pp. 49-56, 2001.

[16] M.Mansour, M.N.Mansouri, and M.F.Mmimouni, Study and Control of a Variable-Speed Wind-Energy System Connected to the Grid, International Journal Of Renewable Energy Research, Vol. 1(Issue 2):96-104, 2011.

[17] Louar Fateh, Ouari Ahmed, Omeiri Amar, Djellad Abdelhak And Bouras Lakhdar, "Modeling and control of a permanent magnet synchronous generator dedicated to standalone wind energy conversion system",Frontiers in Energy, Vol.10, No.2, pp.155-163, June 2016.

[18] D. W. Hart, "Power Electronics', McGraw Hill, 2011.

[19] N. Mohan, Tore M. Undeland, William P. Robbins, "POWER ELECTRONICS:Converters, Applications, and Design", John Wiley \& Sons, 2003. 
[20] M.H.Rashid,"power electronics handbook devices, circuits, and applications", Elsevier Inc, 2011.

[21] Hegazy Rezk, and Ali M. Eltamaly, A comprehensive comparison of different MPPT techniques for photovoltaic systems, Solar Energy, Vol. 112:1-11, February 2015.

[22] Jamel Belhadj and Xavier Roboam, "Investigation of Different Methods to Control a Small Variable-Speed Wind Turbine With PMSM Drives", Journal of Energy Resources Technology, Vol.129, pp.200-213, September 2007.

[23] Adam Mirecki, Xavier Roboam, and Frédéric Richardeau, "Architecture Complexity and Energy Efficiency of Small Wind Turbines", Electrical Power and Energy Systems, IEEE Transactions On Industrial Electronics, Vol. 54, No. 1, pp.660-670, February 2007.

[24] Youcef BEKAKRA, and Djilani BEN ATTOUS, "DFIG sliding mode control fed by back-to-back PWM converter with DC-link voltage control for variable speed wind turbine", Frontiers in Energy, Vol.8, No. 3, pp.345-354, September 2014.

[25] Emil A. Jimenez Brea, Eduardo I. Ortiz-Rivera, Andres Salazar-Llinas and Jesus Gonzalez-Llorente, "Simple Photovoltaic Solar Cell Dynamic
Sliding Mode Controlled Maximum Power Point Tracker for Battery Charging Applications", Twenty-Fifth Annual IEEE Applied Power Electronics Conference and Exposition (APEC), pp.666-671, February 2010.

[26] Hanifi Guldemir, "Sliding Mode Control of Dc-Dc Boost Converter", Journal of Applied Science, Vol. 5, No.3, pp.588-592, 2005.

[27] http://powersimtech.com/. Date accessed: 02/07/2015.

[28] D.MEZGHANI, H.OTHMANI, F.SASSI,MAMI Abdelker,D.T.Geneviève, "A New Optimum Frequency Controller of Hybrid Pumping System: Bond Graph Modeling-Simulation and Practice with ARDUINO Board",International Journal of Advanced Computer Science and Applications(IJACSA), Vol.8, Issue.1, 2017.

[29] A.Shiroudi, R. Rashidi, G. B. Gharehpetian, S. A. Mousavifar, and A. Akbari Foroud, "Case study: Simulation and optimization of photovoltaic-wind-battery hybrid energy system in Taleghan-Iran using HOMER software", Journal of Renewable and Sustainable Energy 4, 053111 (2012). 